\title{
DYNAMICS OF HUMAN CAPITAL DEVELOPMENT IN THE REPUBLIC OF AZERBAIJAN
}

Багірлі Аамія Бадраддін гизи,

докторант, Азербайджанський Університет Туризму і Менеджменту, м. Баку, Азербайджан

\author{
АИНАМІКА РОЗВИТКУ АЮАСЬКОГО КАПІТААУ В АЗЕРБАЙАЖАНСЬКІЙ РЕСПУБАІЦІ
}

The goal of this article is to highlight the dynamics of the development of human capital, the main priorities of the ongoing work and reforms in this area over the past 14 years. The role of the state in the development of human capital, the concern of the head of state in this direction is emphasized.

The study applied such methods as statistical analysis, a comparative analysis of the dynamics of human resources.

The scientific novelty of the study is a statistical comparative analysis of the growth dynamics in the fields of education, healthcare and other social areas.

It is noted that the development of human capital in the policy of the Azerbaijani state is defined as one of the main tasks of the country's future economic strategy. The development strategy of the non-oil sector of the country's economy is aimed at this direction, and a solid foundation has been laid for sustainable development. It is emphasized that the intellectual and technological potential that drives this system, as well as the economic resources that provide powerful financing to support innovative initiatives in the economy, play a vital role. The study of human capital in Azerbaijan is based on a rich scientific base. It is noted that human resources are concentrated in the concept of human capital and turn into a powerful, driving factor.

In conclusion, it is noted that in order to support the development strategy of human capital, a state investment program should be prepared.

It is noted that it is advisable to adapt a mixed approach to the development of human capital, based on both the private and public sectors. In addition to strengthening the targeted government investment program for the private sector, the private sector should be encouraged through tax and administrative mechanisms based on international experience from many countries. However, it should be noted that, despite all the benefits, allocating funds to the field of education only after careful training and a comprehensive assessment of human capital as a whole.

It is noted that the period for a full assessment may be an average of 3-4 years.

The results show that Azerbaijan has become one of the leading countries in the development of human capital, especially among the CIS countries.

Метою статті є висвітлення динаміки розвитку людського капіталу, основних пріоритетів проведеної роботи і реформ у цій галузі за останні 14 років. Підкреслюється роль держави в розвиткулюдського капіталу, турбота глави держави в цьому напрямі.

У дослідженні було застосовано такі методи, як статистичний аналіз, порівняльний аналіз динаміки людських ресурсів.

Наукова новизна дослідження полягає в статистичному порівняльному аналізі зростання динаміки в сферах освіти, охорони здоров'я та інших соціальних галузях. 
Відзначається, що розвиток людського капіталу в політиці азербайджанської держави визначено як одне з основних завдань майбутньої економічної стратегії країни. Стратегія розвиткуненафтового сектору економіки країни націлена на цей напрям, і була закладена міцна основа для сталого розвитку. Підкреслюється, що інтелектуальний і технологічний потенціал, який керує цією системою, а також економічні ресурси, які забезпечують потужне фінансування для підтримки інноваційних ініціатив в економіці, відіграють життєво важливу роль. Дослідженні людського капіталу в Азербайджані заснований на багатій науковій основі. Відзначається, що людські ресурси концентруються в концепції людського капіталу і перетворюються на потужний, рушійний фактор.

У висновку відзначається, що для підтримки стратегії розвитку людського капіталу повинна бути підготовлена державна інвестиційна програма.

Відзначається, що доцільним є адаптація змішаного підходу до розвитку людського капіталу, заснованому як на приватному, так і на державному секторі. Надодаток до посилення цільової урядової інвестиційної програми для приватного сектору, слід заохочувати приватний сектор через податкові та адміністративні механізми на основі міжнародного досвіду багатьох країн. Однак слід зазначити, що, незважаючи на всі пільги, виділяти кошти на галузь освіти тільки після ретельного навчання і комплексної оцінки людського капіталу загалом.

Відзначається, що період для повної оцінки може становити в середньому 3-4 роки.

Результати показують, що Азербайджан став однією з провідних країн у розвитку людського капіталу, особливо серед країн СНД.

Key words: human, human capital, progress, education, health care, social development.

Ключові слова: людина, людський капітал, прогрес, освіта, охорона здоров'я, сочіальний розъиток.

\section{INTRODUCTION}

Human Capital Development in the policy of the Azerbaijani state is defined as one of the main targets of the future economic strategy. The country's oil capital is aimed to this direction, and a solid foundation for the sustainability of national development has been established. Intellectual and technological potential that manages this system, as well as economic resources that provide powerful financing to support innovative initiatives in the economy play a vital role. Human capital in Azerbaijan is based on a rich scientific base. In this regard, resources are concentrated in the concept of human capital and transformed into a powerful, motive factor. Its potential is being increasing.

"Azerbaijan 2020: A look into the future" Development Concept based on the presidential decree dated for December 29, 2012, the transition from the traditional economy to the "Knowledge Economy" has been founded. By all means, the role of human capital is irreplaceable. For this purpose, the organization and level of education is the main factor. This means that the level of financing of education should be within the framework of international standards; $7 \%$ of GDP, $6 \%$ of healthcare and $3 \%$ of science. Therefore, the goal of our country is to pass this level. On this purpose, successful steps are taken [1, p. 9].

The goal of this article is to highlight the dynamics of the development of human capital, the main priorities of the ongoing work and reforms in this area over the past 14 years. The role of the state in the development of human capital, the concern of the head of state in this direction is emphasized.
The study applied such methods as statistical analysis, a comparative analysis of the dynamics of human resources.

The scientific novelty of the study is a statistical comparative analysis of the growth dynamics in the fields of education, healthcare and other social areas.

\section{ANALYSIS OF RECENT PUBLICATIONS ON THIS TOPIC}

It is noted that the development of human capital in the policy of the Azerbaijani state is defined as one of the main tasks of the country's future economic strategy. The development strategy of the non-oil sector of the country's economy is aimed at this direction, and a solid foundation has been laid for sustainable development. It is emphasized that the intellectual and technological potential that drives this system, as well as the economic resources that provide powerful financing to support innovative initiatives in the economy, play a vital role. The study of human capital in Azerbaijan is based on a rich scientific base. It is noted that human resources are concentrated in the concept of human capital and turn into a powerful, driving factor.

Particular attention is paid to the formation, strengthening and development of human capital, which is the most important social-cultural factor of modern economy in Azerbaijan and throughout the world. Today Azerbaijan ranks 78th in the HDI (UN Human Development Index) [2, p.84].

According to the aforementioned dynamics, the lowest indicator among the CIS countries is in Tajikistan (0.664) and the highest indicator is in Russia (0.804) [3, p.104]. As mentioned above, it is necessary to improve human 
capital to upgrade this index. From this point of view, the socio-economic reforms performed in our country are aimed at improving the welfare of each citizen in the Republic. According to the speech of the head of state Ilham Aliyev, the human factor, the improvement of socioeconomic wellbeing of the citizens of the country and the country's entry into the list of highly developed countries are the main goals of multilateral reforms.

In this regard, President Ilham Aliyev has repeatedly mentioned that the increase in oil production and the transformation of "black gold" into human capital are the main goal of the policy of Azerbaijani government and stated: "Our goal is to transfer our oil "our black gold" into the human capital. As a result of our active policy and energy strategy, we have managed to achieve 96 percent of economic growth in the field of political and economic reforms over the past three years. Thanks to the economic reform policy and energy strategy, we have become the fastest growing economy in the world during this period."

Today, Azerbaijan manages the human capital fund and is able to acquire the most advanced knowledge and technology in public and private sectors. Today there are great potential opportunities in our republic. The young and professional cadres of Azerbaijan are contributing to the scientific, technological and cultural development of the world as it is in the modern science and education institutions of the republic.

The young have modern management technologies. In terms of strengthening existing development potential, the young people are considered the golden funds of our country.

Analysis of 2012-2016 shows that the population of Azerbaijan has increased by 5 percent during this period. Since 2012 , the number of economically active population has increased by $6.9 \%$, and total number of employed population has increased $7,1 \%$ : state - by $1.2 \%$ and nonstate - by $9.2 \%$ [4]. While the number of unemployed has increased by $4 \%$, the number of unemployed people, who officially got unemployment status in the employment office, decreased by $10.4 \%$. The number of unemployed beneficiaries has increased by about 2 times (98\%). The number of women working in the economy has increased by $6.5 \%$. (hired). Average monthly salary of the employees has increased by $25.5 \%$. It is noted that, the number of personnel sent to training, as well as the number of managers and specialists decreased by 37.8 and 18.5 percent, respectively [5].

It has been repeated many times training and development of skills is a necessary condition for human development.

\section{STATEMENT OF THE MAIN MATERIAL}

National economic development model of Azerbaijan is based on the social state principles and ensures the development of socially-oriented economy, social welfare and human capital development. Azerbaijan has made remarkable progress in recent years. However, the economic revival may be short in case of the absence of substantial economic diversification, as it is mainly based on the sale of hydrocarbons. This can be achieved by drawing more highly qualified personnel.
In general, five major directions of economic modernization, along with the principles of sustainable economic development and the rapid growth in non-oil sector have been identified in order to achieve economic modernization:

1. Innovative development of economy of Azerbaijan. This is the participation of Azerbaijani companies in the application of modern technologies and the direction of expansion of competitive production and export markets.

2. (market) Strengthening, continuation and dynamic development of marketing institutions. This is the development of entrepreneurship and its investment in the economy.

3. Further diversification of national economy, application of modern technologies, expansion of production, "processing industry" and knowledge economy, increasing competitiveness.

4. To achieve new qualities of human capital, to achieve new qualities to develop creative cadres, the level of preparation to meet the demands of the creative economy.

5 . It is necessary to continue to create more sources of economic growth.

There are already suggestions on how Azerbaijan's trends and reforms will be made to advance human capital in the future. Azerbaijan is expected to be not only economically and politically developed, but also a competitive country in 2020. The income of the population will be high, the unemployment rate will be low, and environmental protection will be improved in the near future in Azerbaijan

In terms of implementation of the goals set out in this concept, institutional capacity will cover three main areas: human resources development in the public sector, the expansion of e-government activities and the continuation of institutional reforms. Execution of the measures such as strengthening social protection and social security system for civil servants, especially in the regions, expanding the fight against corruption, expansion of municipality capacity, preparation of specialists in municipal management and supporting the activities of non-governmental organizations will be continued.

The main factor of the economy of Azerbaijan after 2025 will be the competitive workforce. Special attention will be paid to youth and women in this area. Development of social dialogue and increasing employment will be carried out through organizations providing flexible policy of the labor market. The development of human capital in Azerbaijan, along with the requirements of globalization not only of the national economy but also of the world economy, will allow regulation of labor migration, which will serve to keep more cadres in the country. Increasing technological potential will enable the export of workforce to certain services in Azerbaijan. As a result of the development of the skills and efficiency in the use of workforce, labor productivity in Azerbaijan will reach an appropriate figure at the level of European countries. In general, communication technologies such as high technologies, including the use of high technology, intellectual machine and systems will be developed during the labor market regulation in post -2025 period.

The goal of any economic growth is to develop economic welfare. From now on, the development of social 
Schedule 1. Budget and budget allocations

\begin{tabular}{|c|c|c|c|c|c|c|c|c|c|c|c|c|c|}
\hline $\begin{array}{c}\text { Total } \\
\text { expenditures }\end{array}$ & 2005 & 2006 & 2007 & 2008 & 2009 & 2010 & 2011 & 2012 & 2013 & 2014 & 2015 & 2016 & 2017 \\
\hline Education & 479,1 & 723,0 & 979,7 & 1147,9 & 1180,8 & 1268,5 & 1453,2 & 1437,7 & 1553,9 & 1605,1 & 1754,4 & 1742,7 & 1966,6 \\
\hline Healthcare & 162,0 & 257,2 & 346,2 & 402,4 & 429,2 & 493,4 & 609,4 & 618,9 & 665,3 & 708,2 & 702,5 & 704,7 & 709,9 \\
\hline $\begin{array}{l}\text { Social } \\
\text { protection and } \\
\text { social security }\end{array}$ & 341,5 & 594,8 & 846,4 & 1054,4 & 1123,0 & 1495,4 & 1769,5 & 1750,3 & 1971,2 & 1857,2 & 2645,2 & 2350,2 & 2150,7 \\
\hline $\begin{array}{l}\text { Activities in } \\
\text { culture, art, } \\
\text { information, } \\
\text { physical } \\
\text { education and } \\
\text { areas not } \\
\text { included into } \\
\text { other } \\
\text { categories }\end{array}$ & 67,1 & 95,3 & 140,2 & 158,3 & 168,4 & 189,9 & 240,8 & 274,9 & 294,0 & 272,4 & 687,4 & 253,3 & 299,5 \\
\hline Science & 32,0 & 43,9 & 62,1 & 83,3 & 92,8 & 106,1 & 116,7 & 117,0 & 124,2 & 113,2 & 110,2 & 109,8 & 117,8 \\
\hline
\end{tabular}

[6].

spheres and human capital is one of the key priorities of this concept. The development of the qualities of education and services, strengthening social security, ensuring gender equality, development of family and youth potential and sports play a vital role in this area. The main priority of this conception is to provide health and education services with high quality for the population and easy access to these services for various families, including a few families and poorer citizens as a strategic line. The speed of economic processes has changed all over the world with the gradual qualitative increase of innovations at a new level. This is actually a "positive load" of globalization and it allows more countries to use innovations, advances technical standards and new management methods.

As aforementioned, the state invests to the fields of education, health care, culture, media and sport for the formation and development of human capital. It is true that, these funds play an important role in the economic development of the country. However, it does not mean the efficient use of funs at all times. Sometimes a certain portion of these funds can be made as human capital in the economy of other countries due to the relocation of people who are their carriers. Particularly these cases were more common in the $X X I$ century when the migration processes were widespread. Most developed countries do not allocate any funds to create a certain amount of human capital. So they create conditions for access to the country and availability of human capital.

The expenditure on human capital formation in Azerbaijan is divided into two groups as both budget and private expenditures. Budget expenditures cover the following four groups: 1) expenditures allocated on the education; 2) expenditures allocated to the healthcare; 3 ) expenditures allocated to the science; 4) expenditures allocated to culture, art, media and sports.

Schedule 1 shows the budget and budget allocations as well as the allocation of human capital and their budget share in Azerbaijan over the past 12 years. According to the schedule, in recent years the budget of Azerbaijan has significantly increased. The oil revenues to the State Oil Fund of Azerbaijan and the transfer of a certain part of it create conditions for the rapid increase of the budget expenditures. Undoubtedly, the increase in budget revenues has created wide opportunities to increase the amount of funds allocated to the education, healthcare, science and culture, art, media, sport, etc. The repair and restoration of hundreds of schools built during 12 years in Azerbaijan is an example for its results. The existing medical facilities in Azerbaijan are provided with the latest medical techniques and technologies.

The funds allocated from the budget for the development of education have grown approximately 10 times, and the funds allocated for the development of the health sector have increased 20 times over the past 12 years. It is also referred to the funs allocated from state budget for the development of culture and arts, media and sports. The amount of funds allocated for the development of these areas has been marked by sharp indicators during these years.

At the same time, it should be taken into account that while the volume of funds allocated to human capital is clearly observed with a sharp increase in budget expenditures and absolute volume, share of the total expenditure is constantly decreasing in the budget. Thus, the budget allocations for the formation of human capital in 2000 amounted to $33 \%$ of all budget expenditures. In 2013 and 2014, this share decreased by 12.8 and $14 \%$, respectively. In other words, the social orientation of state budget of Azerbaijan has decreased considerably over the past 14 years [7, p. 184]. As the budget expenditures were directed to more infrastructure projects over the years, the share of expenditures for the formation of human capital from the budget decreased

The structure and dynamics of expenditures allocated from family budgets for the development of human capital are indicated over the past 14 years. As mentioned before, this schedule is based on the official statistics and the funds allocated from family budget for education and healthcare is not reflected in the schedule. As the majority of the population in the Azerbaijan does not use health insurance, the health care expenditures are allocated from family budget.

However, according to the schedule 2, these expenditures do not constitute the largest share of the family budget in accordance with official statistics. We can also observe the same indicators in the education costs. For 


\section{Schedule 2. The allocations family budget}

\begin{tabular}{|l|l|l|l|l|}
\hline Year & $\begin{array}{c}\text { Budget } \\
\text { expenditures }\end{array}$ & $\begin{array}{c}\text { Expenditures } \\
\text { of family } \\
\text { budget }\end{array}$ & $\begin{array}{c}\text { General } \\
\text { expenditures }\end{array}$ & $\begin{array}{c}\text { Share of } \\
\text { state } \\
\text { budget }\end{array}$ \\
\hline 2005 & 599,6 & 38,4 & 638 & 0,93 \\
\hline 2006 & 828,4 & 42 & 870 & 0.91 \\
\hline 2007 & 1304 & 50,4 & 1355 & 0,92 \\
\hline 2008 & 1806 & 58,8 & 1918 & 0.93 \\
\hline 2009 & 2229 & 73,2 & 2302 & 0.93 \\
\hline 2010 & 2331 & 91,2 & 2422 & 0.95 \\
\hline 2011 & 2606 & 118,8 & 2724 & 0.96 \\
\hline 2012 & 3080 & 157,2 & 3237 & 0.97 \\
\hline 2013 & 3121 & 175,2 & 3296 & 0.95 \\
\hline 2014 & 3362 & 193 & 3555 & 0.95 \\
\hline 2015 & 3512 & 202 & 3715 & 0.94 \\
\hline 2016 & 3610 & 214 & 3824 & 0.96 \\
\hline 2017 & 3843 & 243 & 4086 & 0.96 \\
\hline
\end{tabular}

[6].

example, the upper class students of high school go private training courses by paying high fees. Thus, most of the family budget is spent on such payments. It should be noted that, despite the fact that the largest share of the family budget was not spend in education and health care, according to the official statistics, the proportion of these expenditures has increased continuously over the past 12 years. Although the expenditure was $3 \%$ in 2005 , the figure reached $6,8 \%$ in 2017 [6].

Additionally, as public health care expenditures of people are not mentioned in official statistics, their average expenditure share is not taken into consideration. According to the statistical data of World Health organization, special expenditures allocated to the health care in Azerbaijan was 758 (international) dollars in 2013. This is at least three times higher than the amount of healthcare costs indicated Schedule 2.

Such significant differences between formal and informal payments made from family budgets on health care costs are clearly highlighted in reports jointly prepared by the Ministry of Health of the Republic of Azerbaijan and the World Health Organization.

Another very interesting fact is that the share of expenditures on education and health from the family budget has been steadily increasing since 2008 . The growth of the amount of the funds allocated from the family budget for the development of these fields is mainly related to the level of economic liberalization; at the same time the total amount allocated from the state budget is declining. In this regard, more serious steps have been taken to liberalize the economy of Azerbaijan. However, despite the tendency to increase the expenditure on education and health expenditures from the family budget, expenditures from the state budget for total consumption expenditures are still quite high.

According to the Schedule 2, the allocations from family budget are few as compared to the expenditures allocated from state budget to the formation of human capital. Over these years, the volume of funds allocated from the state budget for the formation of human capital has increased from $90 \%$ to $96 \%$. If there were no unofficial expenditure on education and health from the family budget, these figures could be considered high for a country that favored liberalization for economic development. However, due to the fact that the unofficial expenditure of the population from their own budget is not reflected in the official statistics, it can not be said without doubt about the high share of state expenditures in the formation of human capital.

\section{CONCLUSION}

In order to support the development strategy of the Human Capital, a public investment program should be prepared. As mentioned above, we consider the adaptation of a mixed approach to the development of Human Capital that is relying on private and public partnership more appropriate. In addition to strengthening the private sector targeted government investment program, the private sector should be encouraged through tax and administrative mechanisms. From this point of view, there are many international experiences that are also advisable. For example, countries such as the Chechen Republic and Malaysia are actively using professional training grants for investors. Norway and Kazakhstan jointly invest in the allocation of grants for national employers, and there is a special fund in Singapore, this fund is engaged in the financing of professional study. In this regard, there are tax privileges in many countries. However, it should be noted that, despite that, to allocate funds for the field of education is wrong prior to full assessment of human capital. The period for the complete assessment may be $3-4$ years.

\section{References:}

1. Mustafaev, O. (2014). Mustafayev, O. [Creation of public-business partnership system in education. Journal 'Azerbaijanian teachers'.] Tehsil sahesinde dovlet-biznes partnyorlugu sisteminin yaradilmasi. Azerbaycan muellimi. 7 mart, s.9.

2. (2016). [Strategic Roadmap for National Economy Perspectives of the Republic of Azerbaijan] Azerbaycan Respublikasinin milli iqtisadiyyat perspektivi uzre Strateji Yol Xeritesi / http://edu.gov.az/upload/file/ serencama-elave/2016/strateji-yol-xeritesi.pdf (12.02.2020)

3. Veliev,llqar (2018). Veliev, Ilqar [Statistical analysis of the effects of atmospheric pollution on health and life expectancy / Scientific-practical journal "Statistics News". Baku], Atmosferin sirklenmesinin ehalinin saglamligina ve omur uzunluguna tesirinin statistik tehlili/ "Statistika xeberleri" elmi-praktik jurnal. Baki, seh, 104,

4. https://www.stat.gov.az/source/demoqraphy/ (12.02. 2020)

5. (2017). [Report of the Ministry of Labor and Social Protection of the Republic of Azerbaijan for 2017] Azerbaycan Respublikasi Emek ve Ehalinin Sosial Mudafiesi Nazirliyinin 2017-ci il uzre hesabati/ http:// sosial.gov.az/uploads/images/image_750x_5c62a9ac5d584.pdf (12.02.2020).

6. https://www.stat.gov.az/(12.02.2020).

7. Musaev, A. (2014). Musayev, A. [Innovation economy and tax incentives. Baku. Publishing house "Azerbaijan University"], Innovasiya iqtisadiyyati ve vergi stimullasdirmasi. Baki. "Azerbaycan Universiteti" nesriyyati, $184 \mathrm{~s}$.

Стаття надійшла до редакиії 16.02.2020 p. 